\title{
Hubungan serum seng dengan jumlah CD4 pada lansia di Panti Jompo
}

\author{
Maria Widijanti Sugeng ${ }^{1}$, Merryana Adriani $^{2}$, Bambang Wirjatmadi ${ }^{2}$
}

\begin{abstract}
Background: Elderly people tend to have higher susceptibility to infections because of immune dysfunction, especially cell-mediated immune system which is related to zinc deficiency. Zinc has an important role in the cellmediated immune system which can be determined by CD4 count.

Objectives: To determine the zinc level in the serum and CD4 count in healthy elderly and the correlation between the zinc level in the serum and CD4 count.

Method: This was a randomized cross-sectional study. Twenty seven healthy elderly subjects of both sexes aged 60-90 years were recruited for this study from a senior center. Zinc level in the serum and CD4 count were measured.

Result: The average of CD4 count was $710 \pm 269$ cells $/ \mathrm{ml}$, and the average of zinc level in the serum was $87,29 \pm$ $10,27 \mu \mathrm{g} / \mathrm{dL}$. Twenty six percent elderly had low CD4 count $(<460 \mathrm{cell} / \mathrm{ml}$. There was no zinc deficiency among the elderly but $30 \%$ elderly had zinc level $70-80 \mu \mathrm{g} / \mathrm{dL}$. There was a significant correlation $(p<0,05)$ between zinc level and CD4 count, which was analyzed using Pearson correlation method.
\end{abstract}

Conclusion: CD4 count has correlation with zinc level in the serum in elderly

Keywords: Zinc level, CD4 count, elderly

\section{PENDAHULUAN}

Keberhasilan pembangunan di bidang kesehatan di Indonesia membawa dampak pada peningkatan Usia Harapan Hidup (UHH) dan jumlah penduduk lanjut usia (lansia) yang berumur lebih dari 60 tahun. Jika tahun 1980 Usia Harapan Hidup (UHH) penduduk Indonesia 52,2 tahun dan jumlah lansia 7.998 .543 orang $(5,45 \%)$. Pada tahun 2010 jumlah lansia sudah menjadi 18,04 juta jiwa (7,59 \%) dengan UHH 67,4 tahun. Pada tahun 2020 jumlah lansia diperkirakan menjadi sekitar 28,882 juta jiwa (11,34\%) dengan UHH sekitar 71,1 tahun (Depsos, 2012).

Peningkatan jumlah lansia ini diikuti dengan peningkatan masalah kesehatan pada lansia termasuk penyakit infeksi yang biasanya disebabkan adanya penurunan sistem imunitas. Penurunan sistem imunitas ini terutama terjadi akibat proses penuaan serta adanya defisiensi zat gizi yang diperlukan dalam peningkatan sistem imunitas tubuh, termasuk salah satunya mineral seng (Prasad et al, 1993).

Proses penuaan mengakibatkan perubahan anatomis dan fungsi organ yang bertanggungjawab terhadap imunitas, diantaranya adalah kelenjar timus yang mengalami atrofi. Akibat atrofi kelenjar timus, terjadi penurunan produksi hormon Thymulin yang merupakan hormon spesifik kelenjar timus dan dibutuhkan untuk proses diferensiasi dan pematangan sel $T$ helper (Th1), menginduksi beberapa marker pada sel $\mathrm{T}$, meningkatkan fungsi sel $\mathrm{T}$, termasuk sitotoksik alogenik, dan produksi
IL2 (Interleukin 2). Hormon thymulin membutuhkan seng sebagai ko-faktor untuk melakukan aktivitas biologinya. Aktifitas hormon Thymulin diukur melalui serum thymulin activity. Bila serum thymulin activity menurun, maka Th1 akan menurun, sehingga terjadi penurunan sel CD4 baru. Selain itu penurunan thymulin juga mengakibatkan penurunan aktivitas sel natural killer dan sel $\mathrm{T}$ sitolitik yang banyak berperan untuk membunuh, bakteri dan sel tumor (Prasad, 2007).

Sel CD4 adalah bagian sel limfosit $\mathrm{T}$ (subset limfosit T) yang mengekspresikan molekul CD4 pada permukaan sel. Istilah $\mathrm{CD}$ adalah singkatan dari cluster of differentiation yang mengacu ke suatu molekul yang dikenal oleh sekelompok (cluster) antibodi monoklonal yang dapat digunakan untuk mengidentifikasi stadium diferensiasi limfosit. CD4 merupakan marker sel $T$ helper yang berperan penting dalam imunitas tubuh, terutama imunitas adaptif (acquired) yang berbasis sel (cell mediated immunity) (Prasad, 2007).

Secara umum pada lansia, sistem imun berbasis sel (cell- mediated immunity) lebih menunjukkan penurunan dibandingkan dengan imunitas humoral. Kapasitas sel limfosit $\mathrm{T}$ pada darah perifir untuk bermultiplikasi setelah

\footnotetext{
${ }^{\mathrm{I}}$ Magister Ilmu Kesehatan Masyarakat Universitas Airlangga (UNAIR). Surabaya, Jawa Timur.

${ }^{2}$ Fakultas Kesehatan Masyarakat, Universitas Airlangga (UNAIR), Surabaya, Jawa Timur
} 
ada rangsangan pada lansia lebih rendah dibandingkan kelompok usia muda. Pada lansia dijumpai adanya penurunan jumlah limfosit pada darah tepi seiring dengan bertambahnya umur. Pada lansia yang sehat, penurunan hanya sekitar $10-15 \%$ dari jumlah limfosit normal. Penuaan juga ditandai dengan penurunan sel Th1 subset (CD4). Jumlah CD4 ini semakin rendah bila terjadi infeksi pada lansia (Lesourd, 1997).

Defisiensi seng sering terjadi pada lansia, dan biasanya disertai dengan penurunan aktivitas thymulin dan produksi IL-2 yang rendah yang mengindikasikan adanya atrofi kelenjar timus. Pada beberapa penelitian menunjukkan bahwa kadar seng mempengaruhi jumlah CD4 dan pemberian suplemen seng bisa meningkatkan imunitas, sehingga mengurangi frekuensi kejadian dan durasi infeksi saluran pernafasan dan diare (Prasad et al., 2007). Seng juga berperan dalam imunitas innate (tidak spesifik) dan adaptive (spesifik). Seng berperan untuk menjaga supaya sel imun innate seperti neutrofil, monosit, makrofag, sel natural killer serta sel imun adaptive seperti sel limfosit $\mathrm{T}$ dan $\mathrm{B}$ bisa berfungsi normal (Haase et al., 2006).

Penyakit infeksi yang menyerang lansia masih cukup tinggi sebagai akibat sistem imunitas pada lansia yang menurun, terutama imunitas berbasis sel. Yoshikawa (1995) menemukan data kematian akibat infeksi pada lansia di Amerika Serikat bahwa angka kematian pneumonia, sepsis dan meningitis bakterialis pada lansia sekitar 3 kali lebih tinggi dibandingkan pada dewasa muda (Hadisaputro dan Martono, 2006). Berdasarkan penelitian yang dilakukan di RSUP Kariadi pada tahun 1991-1994, penyakit infeksi pada lansia yang terbanyak adalah Infeksi Saluran Pernafasan Akut (bronkopneumonia), Infeksi Saluran Kencing (ISK), sepsis dan gastroenteritis. Angka kematian tertinggi pada lansia akibat infeksi disebabkan oleh sepsis dan bronkopneumonia (Hadisaputro dan Martono, 2006).

Lansia yang tinggal di panti jompo atau panti sosial lebih rentan terkena infeksi saluran pernafasan, terutama ISPA yang disebabkan oleh influenza, parainfluenza, and respiratory syncytial viruses (Meydani et al., 2004). Influensa termasuk dalam 4 (empat) penyebab penyakit infeksi tersering yang diderita lansia di panti jompo, selain skabies, Clostridium difficile, and methicillinresistant Staphylococcus aureus (Mathei et al., 2007). Data penyakit infeksi di panti jompo di Indonesia masih sulit didapatkan, tetapi diperkirakan bahwa infeksi saluran pernafasan, gastroenteritis serta infeksi saluran kemih termasuk penyakit infeksi yang sering diderita para lansia di panti jompo di Indonesia.

Tujuan penelitian ini untuk mengetahui hubungan antara serum seng dengan jumlah CD4 pada lansia yang tinggal di Panti Jompo, serta untuk mencari prevalensi penurunan kadar serum seng dan jumlah CD4 pada kelompok lansia tersebut. Hasil penelitian ini digunakan untuk melanjutkan penelitian tentang Pengaruh pemberian seng dan lisin terhadap kejadian infeksi dan jumlah CD4 pada lansia.

\section{METODE DAN BAHAN}

Penelitian ini merupakan penelitian pendahuluan terhadap 27 orang lansia yang tinggal di sebuah Panti Jompo, dipilih secara acak, terdiri dari 11 pria dan 16 wanita, yang diikutsertakan dalam penelitian lanjutan tentang "Pengaruh pemberian seng dan lisin terhadap kejadian infeksi dan jumlah CD4 pada lansia". Kriteria inklusi penelitian ini adalah lansia yang tinggal di sebuah Panti Jompo di Surabaya, berumur minimal 60 tahun atau lebih (rerata 74,6 \pm 7,4 tahun, dengan rentang 60-90 tahun), tidak dalam keadaan sakit infeksi kronis, kanker atau gagal organ, serta bersedia berpartisipasi dalam penelitian ini dengan menandatangani informed consent. Penelitian ini juga sudah disetujui komite etik Fakultas kesehatan Masyarakat Universitas Airlangga Surabaya. Karena penelitian ini adalah penelitian pendahuluan, maka jumlah responden disesuaikan dengan rumus Lemeshow (1997) untuk penelitian lanjutan yang bersifat eksperimental dengan 3 kelompok penelitian yang akan dilakukan segera setelah penelitian pendahuluan ini. Jumlah sampel minimal untuk penelitian tersebut setelah ditambah faktor koreksi $10 \%$ adalah 27 sampel dengan nilai $\alpha=0,05$ dan nilai $\beta=0,2$.

Pengambilan sampel darah sebanyak $8 \mathrm{ml}$ dan ditempatkan pada vacutainer dengan antikoagulan EDTA. Pengukuran jumlah CD4 menggunakan metode flow cytometry dengan alat BD FACSCount ${ }^{T M}$ (BD Biosciences, 2010) dan dikerjakan di Laboratorium Prodia Surabaya yang telah berstandar ISO 9001. Sedangkan metode yang digunakan untuk mengukur kadar serum seng adalah Atomic Absorption Spectrophotometry (AAS) dan dikerjakan di Balai Besar Laboratorium Kesehatan Surabaya yang juga telah berstandar ISO 9001.

Hipotesa penelitian ini adalah terdapat hubungan antara kadar serum seng dengan jumlah CD4 pada lansia. Uji korelasi Pearson digunakan untuk mencari ada atau 
tidaknya hubungan antara kadar serum seng dengan jumlah CD4.

\section{HASIL}

Karakteristik demografi responden lansia bisa dilihat pada Tabel 1. Umur rerata responden lansia adalah 74,6 \pm 7,4 tahun, dengan rentang 60-90 tahun. Responden wanita lebih banyak dibandingkan pria yaitu sekitar $59 \%$. Penyakit penyerta non infektif yang paling banyak diderita adalah hipertensi, yaitu sekitar 96\%. Penyakit penyerta lainnya adalah riwayat stroke (22\%), osteoarthritis $(11 \%)$, gastritis $(7 \%)$, hiperkolesterolemia (7\%), diabetes melitus (4\%), penyakit jantung koroner (4\%) dan glaukoma (4\%).

Tabel 1. Karakteristik demografi lansia

\begin{tabular}{|c|c|}
\hline Variabel & $\begin{array}{l}\text { Responden lansia } \\
(\mathrm{n}=27)\end{array}$ \\
\hline Umur & $74,6+7,4$ tahun \\
\hline \multicolumn{2}{|l|}{ Jenis Kelamin : } \\
\hline - Pria & $11(40.7 \%)$ \\
\hline - Wanita & $16(59.3 \%)$ \\
\hline \multicolumn{2}{|l|}{ Riwayat Penyakit: } \\
\hline - Hipertensi & $26(96.3 \%)$ \\
\hline - Riwayat Stroke & $6 \quad(22.2 \%)$ \\
\hline - Osteoarthritis & $3(11.1 \%)$ \\
\hline - Gastritis & $2(7.4 \%)$ \\
\hline - Hiperkolesterolemia & $2(7.4 \%)$ \\
\hline - Diabetes Melitus & $1(3.7 \%)$ \\
\hline $\begin{array}{l}\text { - Penyakit jantung } \\
\text { koroner }\end{array}$ & $1 \quad(3.7 \%)$ \\
\hline - Glaukoma & $1(3.7 \%)$ \\
\hline
\end{tabular}

Pada Tabel 2. bisa dilihat rerata jumlah CD4 responden lansia adalah $710 \pm 269$ sel CD4/ml dengan rentang 323-1341 sel/ml. Nilai normal CD4 untuk dewasa adalah 460-1600 sel/ml. Sedangkan rerata kadar serum seng responden lansia adalah 87,29 $\pm 10,27 \mu \mathrm{g} / \mathrm{dL}$ dengan rentang 71,59-109,48 $\mu \mathrm{g} / \mathrm{dL}$. Nilai normal serum seng untuk dewasa adalah 70-150 $\mu \mathrm{g} / \mathrm{dL}$. Tujuh dari dua puluh tujuh (sekitar 26\%) responden lansia mempunyai jumlah CD4 di bawah nilai normal, yaitu kurang dari 460 sel/ml. Sekitar $85 \%$ responden lansia mempunyai jumlah CD4 kurang dari $1000 \mathrm{sel} / \mathrm{ml}$ dan sekitar $63 \%$ mempunyai jumlah CD4 kurang dari $800 \mathrm{sel} / \mathrm{ml}$ seperti terlihat pada Gambar 1. Tidak ada responden lansia yang mengalami defisiensi seng dengan kriteria batas normal kadar serum seng adalah $70 \mu \mathrm{g} / \mathrm{dL}$.
Tabel 2. Jumlah CD4 dan kadar serum seng pada responden lansia

\begin{tabular}{|c|c|c|}
\hline $\begin{array}{l}\text { Nomor } \\
\text { Responden }\end{array}$ & $\begin{array}{c}\text { Jumlah } \\
\text { CD4 }\end{array}$ & $\begin{array}{c}\text { Kadar } \\
\text { Serum Seng }\end{array}$ \\
\hline 1 & 400 & 82.36 \\
\hline 2 & 457 & 76.64 \\
\hline 3 & 491 & 71.59 \\
\hline 4 & 439 & 88.09 \\
\hline 5 & 356 & 96.86 \\
\hline 6 & 406 & 75.92 \\
\hline 7 & 842 & 87.09 \\
\hline 8 & 539 & 88.39 \\
\hline 9 & 323 & 88.47 \\
\hline 10 & 654 & 93.56 \\
\hline 11 & 1048 & 101.43 \\
\hline 12 & 710 & 90.55 \\
\hline 13 & 839 & 102.52 \\
\hline 14 & 371 & 72.92 \\
\hline 15 & 528 & 84.98 \\
\hline 16 & 890 & 82.93 \\
\hline 17 & 740 & 88.64 \\
\hline 18 & 1341 & 82.7 \\
\hline 19 & 731 & 103.59 \\
\hline 20 & 1233 & 109.48 \\
\hline 21 & 1005 & 87.49 \\
\hline 22 & 878 & 94.67 \\
\hline 23 & 715 & 99.84 \\
\hline 24 & 884 & 86.39 \\
\hline 25 & 946 & 77.78 \\
\hline 26 & 678 & 74.91 \\
\hline 27 & 742 & 77.02 \\
\hline Mean (Rerata) & 710 & 87.29 \\
\hline Standar Deviasi & 269 & 10.27 \\
\hline
\end{tabular}

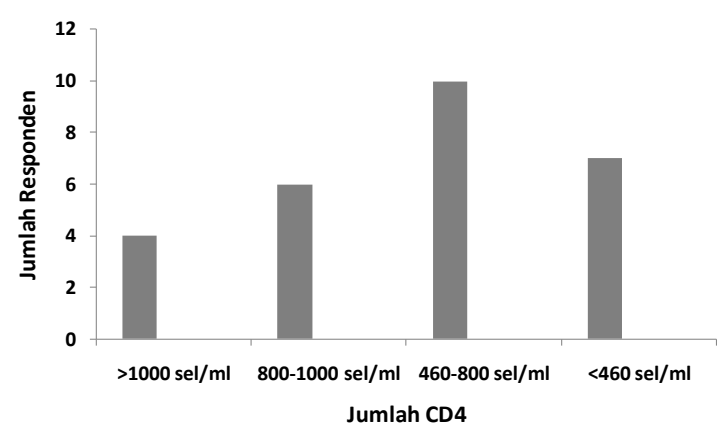

Gambar 1. Gambaran jumlah CD4/ml darah pada responden lansia 


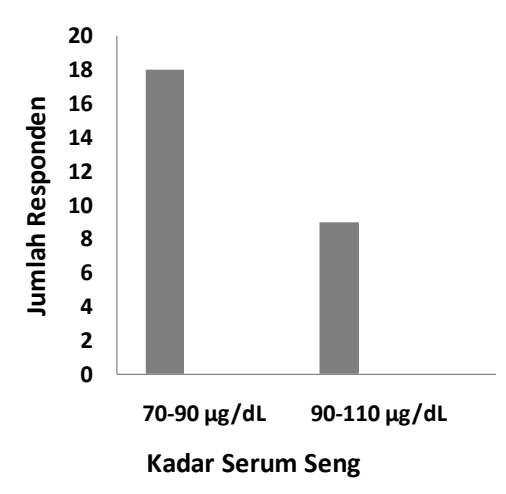

Gambar 2. Gambaran kadar serum seng pada responden lansia

Meskipun kadar seng normal, sebanyak delapan belas orang lansia atau sekitar $67 \%$ responden mempunyai kadar serum seng yang rendah, yaitu di bawah $90 \mu \mathrm{g} / \mathrm{dL}$ atau disebut juga defisiensi seng marginal. Hanya 33\% responden yang mempunyai kadar serum seng benarbenar normal, seperti terlihat pada Gambar 2.

Karena data berdistribusi normal dengan uji Kolmogorov-Smirnov, maka digunakan analisa korelasi dengan metode Pearson. Pada hasil analisa ditemukan adanya hubungan yang signifikan antara kadar serum seng dengan jumlah CD4 dengan $\mathrm{p}<0,05$ dan koefisien korelasi 0,414 .

\section{PEMBAHASAN}

Kadar serum seng pada responden lansia berada dalam batas normal yaitu $87,29 \pm 10,27 \mu \mathrm{g} / \mathrm{dL}$ sesuai dengan hasil penelitian lain pada kelompok lansia sehat di Italia yaitu sekitar $88, \pm 5,8 \mu \mathrm{g} / \mathrm{dL}$, yang memang lebih rendah dari kadar serum seng pada kelompok dewasa muda (2030 tahun) yaitu $120,0 \pm 6,5 \mu \mathrm{g} / \mathrm{dL}$. Pada penelitian tersebut kadar serum seng pada lansia dengan penyakit infeksi akut bronkopneumonia juga diperiksa, dan ternyata hasilnya lebih rendah daripada lansia yang sehat yaitu 75,3 $\pm 3,2 \mu \mathrm{g} / \mathrm{dL}$. Pada lansia dengan infeksi bronkitis obstruktif kronis juga ditemukan penurunan kadar serum seng yaitu 76,8 $\pm 4,3 \mu \mathrm{g} / \mathrm{dL}$ (Mocchegani et al., 1999). Kadar serum seng pada penelitian kami lebih rendah dibandingkan dengan penelitian serupa di Detroit, Amerika Serikat di mana ditemukan kadar serum seng pada lansia sehat adalah $94,3 \pm 11,4 \mu \mathrm{g} / \mathrm{dL}$. Sekitar $35 \%$ responden lansia sehat pada penelitian tersebut dikatakan menderita defisiensi seng berdasarkan kadar serum seng yang kurang dari $90 \mu \mathrm{g} / \mathrm{dL}$ (Prasad et al., 2007), sedangkan pada penelitian kami, kriteria defisiensi seng adalah kadar serum seng kurang dari $70 \mu \mathrm{g} / \mathrm{dL}$ (Haase et al., 2006). Dari segi umur, rerata umur responden kami (74,6 \pm 7,4 tahun) juga lebih tua dibandingkan dengan rerata umur responden yang digunakan di Amerika Serikat (65 \pm 9 tahun) (Prasad et al., 2007).

Penurunan kadar serum seng pada lansia juga disertai dengan penurunan jumlah CD4. Jumlah CD4 pada responden lansia yaitu $710 \pm 269 \mathrm{sel} / \mathrm{ml}$, lebih rendah dibandingkan penelitian yang sama di Italia yaitu $877 \pm$ $47 \mathrm{sel} / \mathrm{ml}$. Pada penelitian tersebut ditemukan bahwa jumlah CD4 pada kelompok dewasa muda lebih tinggi yaitu $925 \pm 68 \mathrm{sel} / \mathrm{ml}$. Sedangkan jumlah CD4 menurun lebih banyak pada kelompok lansia dengan infeksi akut dan kronis. Jumlah CD4 kelompok lansia dengan infeksi akut adalah $457 \pm 53 \mathrm{sel} / \mathrm{ml}$ dan pada infeksi kronis adalah $460 \pm 66 \mathrm{sel} / \mathrm{ml}$ (Mocchegani et al., 1999).

Hubungan antara kadar serum seng dan jumlah CD4 yang ditemukan pada penelitian ini juga ditunjukkan pada penelitian yang sama di Italia, yaitu dengan suplementasi seng $12 \mathrm{mg}$ per hari selama 1 bulan pada lansia dengan infeksi kronis bisa meningkatkan jumlah CD4 dari $462 \pm$ $48 \mathrm{sel} / \mathrm{ml}$ menjadi $690 \pm 41 \mathrm{sel} / \mathrm{ml}$ (Mocchegani et al., 1999). Pada penelitian lain tentang sub populasi sel $T$ juga menunjukkan bahwa status seng berhubungan dengan jumlah CD4 dan rasio CD4/CD8. Defisiensi seng menyebabkan penurunan jumlah CD4 dan perubahan rasio CD4/CD8 dan hal ini bisa dikoreksi dengan suplementasi seng (Beck et al., 1997). Defisiensi seng mengakibatkan penurunan aktivitas thymulin dan produksi IL-2 yang berdampak pada penurunan fungsi imunitas berbasis sel, termasuk penurunan jumlah CD4 (Prasad et al., 2007).

\section{KESIMPULAN}

Kadar serum seng dan jumlah CD4 pada lansia cenderung rendah. Meskipun kadar serum seng masih dalam batas normal, tetapi berada pada batas bawah (defisiensi marginal). Penurunan jumlah CD4 pada lansia berhubungan dengan penurunan kadar serum seng karena seng mempengaruhi aktivitas hormon thymulin yang diperlukan dalam pembentukan dan diferensiasi sel limfosit $\mathrm{T}$.

\section{DAFTAR PUSTAKA}

BD Biosciences. 2010. BD FACSCount CD4 Reagents. San Jose: BD Biosciences.

Beck, F., Prasad, A., Kaplan, J., Fitzgerald, J., \& Brewer, G. 1997. Changes in cytokine production and T cell subpopulations in experimentally induced zinc- 
deficiency humans. American Journal of Physiology. 272(6): E1002-7.

Depsos. 2012. Perkembangan Lanjut Usia di Indonesia.

(On Line). Retrieved August 29, 2012, from Kementerian Sosial Republik Indonesia. URL: http://www.kemsos.go.id/modules.php?name=News\& file $=$ article $\&$ sid $=16984$

Haase, H., Mocchegiani, E., \& Rink, L. 2006. Correlation between zinc status and immune function in the elderly. Biogerontology. 7(5-6): 421-428.

Hadisaputro, S., \& Martono, H. 2006. Infeksi Pada Usia Lanjut. In R. B. Darmojo, Buku Ajar Geriatri (pp. 355-390). Jakarta: Balai Penerbit FK UI.

Lesourd, B. M. 1997. Nutrition and Immunity in the Elderly: Modification of Immune Response with Nutritional Treatments. American Journal of Clinical Nutrition. 66(2): 478S-484S.

Mathei, C., Niclaes, L., Suetens, C., Jansb, B., \& Buntinx, F. 2007. Infections in Residents of Nursing Homes. Infectious Disease Clinical North America. 21(3): 761-72. Meydani, S., Leka, L., Fine, B., Dallal,
G., Keusch, G., Singh, M., et al. 2004. Vitamin E May Reduce Some Respiratory Infections in Elderly Nursing Hone Residents. JAMA. 292(7): 828-836.

Mocchegani, E., Muzzioli, M., Gaetti, R., Veccia, S., Viticchi, C., \& Scalise, G. 1999. Contribution of Zinc to reduce CD4 risk factor for severe infection relapse in aging: parallelism with HIV. International Journal of Immunopharmacology. 21(4): 271-281.

Prasad, AS, Fitzgerald, JT, Hess, JW, Kaplan, J, Pelen, F, Dardenne, M. 1993: Zinc Deficiency in Elderly Patients. Journal of Nutrition. 9(3): 218-224.

Prasad, AS. 2007. Zinc: Mechanisms of Host Defense. Journal of Nutrition. 137(5): 1345-1349.

Prasad, AS, Beck, FWJ, Bao, B, Fitzgerald, JT, Snell, DC, Steinberg, JD. 2007. Zinc supplementation decreases incidence of infections in the elderly: effect of zinc on generation of cytokines and oxidative stress. American Journal of Clinical Nutrition. 85(3): 837-844. 